\title{
Exploring Options for Enhancement of Social Dialogue Between the Turkish and Greek Communities in Cyprus Using the Structured Dialogic Design Process
}

\author{
Yiannis Laouris · Ali Erel · Marios Michaelides · Mustafa Damdelen • \\ Tatjana Taraszow · Ilke Dagli · Romina Laouri $\cdot$ Aleco Christakis
}

Published online: 13 May 2009

(C) The Author(s) 2009. This article is published with open access at Springerlink.com

\begin{abstract}
This paper summarizes results of a co-laboratory that took place 33 months after the negative outcome of the referendum on the UN's proposal for the solution of the Cyprus problem, and which was a follow-up (3 months later) of a previous co-laboratory. The earlier co-laboratory explored factors contributing to the increasing gap between the two conflicting communities. The co-laboratory reported here engaged relevant stakeholders (peace pioneers, academics, business people, activists and others representing the Turkish and Greek speaking communities of Cyprus) to come up with options aiming to enhance the social dialogue between the two communities. The Structured Dialogic Design Process was used to structure 27 proposed options and develop an influence map. The deep drivers, i.e., most influential factors, determined decisions taken by the participating peace pioneers regarding their future interventions. The results are also discussed within the framework of current (analysis reflects the political situation during the period reported here) political developments.
\end{abstract}

Keywords Cyprus - Peace - Referendum - Structured Dialogic Design Process · Collective wisdom - Law of requisite action - Interactive management .

Complex system · Dialogue - Social system design · Agora - Democracy ·

Stakeholders · Technology of democracy $\cdot$ Learning community $\cdot$ Co-laboratories

Y. Laouris $(\bowtie) \cdot T$. Taraszow $\cdot$ R. Laouri

Cyprus Neuroscience \& Technology Institute, Nicosia, Cyprus

e-mail: laouris@cnti.org.cy

A. Erel · M. Damdelen · I. Dagli

Cyprus EU Association, Lefkosia, Cyprus

Y. Laouris - M. Michaelides - T. Taraszow

Cyprus Intercultural Training Initiative, Nicosia, Cyprus

A. Christakis

Institute for 21st Century Agoras, Crete, Greece 


\section{Introduction}

Years 2003 and 2004 were marked as Grand milestones in the recent history of Cyprus. On the 23rd of April 2003, the partial opening of three "Gates" enabled Turkish Cypriots (TC) and Greek Cypriots (GC) to cross and visit the other half of their country for the first time after almost 30 years of complete separation. The event was covered by media worldwide. One year later, on the 24th of April 2004, Cypriots were called, in separate referenda, to vote on a comprehensive plan for the resolution of the Cyprus problem, known as the Annan plan. With $76 \%$ of the GC voting "No", and 65\% of TC voting "Yes", the failure to end the protracted Cyprus problem and re-unify the island left behind a climate of disappointment not only among those who worked and hoped for a final political settlement of the Cyprus problem, i.e., the UN, the EU, the international community and the local peace builders (Anastasiou 2007; EuropaWorld 2004; local and international media in the period following the referendum). Moreover it produced a feeling of desperation and disempowerment among ordinary people (Christophorou and Webster 2004) that came a year after the previous failure (PSEKA 2003). It also created strong disagreements within opposite political groupings and even within ordinary people as to what next steps could or should be taken in order to evade the impasse. The political leaders and the Cypriot people at large failed to bring an end to their long struggle for peace, co-existence and growth within the European context. The reactions were different on the two sides of the Green Line. In the South, some political analysts (Christophorou and Webster 2004; Droushiotis 2005) held President Papadopoulos responsible for the failure of a negotiation process that lasted over 5 years. However, being in power, enjoying the support of a great majority and backed up by adversarial media, his administration blamed the previous governments in Cyprus, the UN and foreign stakeholders for the failure. They also publicly tarnished the reputations of peace pioneers and those who voted "Yes" by claiming they had been rewarded millions of dollars by the US government to support and promote the Annan plan. The House of Representatives, through its Institutions' Committee, threatened to "investigate" ungrounded allegations against Cypriots in the period leading to the referendum, pre-assuming that such foreign interventions indeed took place. Both the citizens' and political environment became extremely polarized like never before.

In the northern part, the masses that supported the "Yes" felt betrayed by the GC side. The political leadership encouraged the partial implementation of measures included in the Annan plan such as those concerning property issues. This led to massive and environmentally distracting construction developments throughout the northern part of the island. Such developments complicate enormously the resolution of property disputes, even after an agreed solution.

It was within this agitated negative climate that a group of peace pioneers launched an initiative to re-activate civil society dialog in the summer of 2006 (reported in Laouris et al. 2009; see also Civil Society Dialogue Project in references). They anticipated they could contribute to the revival of the peace process and peoples' hope for resolution of the Cyprus problem. The initiative was originally inspired by a team of six veteran peace pioneers (members of the peace group, widely known as "Conflict Resolution Trainers Group"-CRTG; ${ }^{1}$ Broome 1998, 2005; Wolleh 2001; Laouris 2004), who decided to

\footnotetext{
1 This CRTG group of 32 GCs and TCs participated earlier in numerous problem solving, leadership, project management and design sessions focused on peace building efforts in Cyprus. Between the fall of 1994 and the winter of 1997 they met on a weekly basis first in separate (North and South) and subsequently in joint community meetings. They managed to develop very detailed Vision-, Obstacles- and Options Maps
} 
discuss the current ${ }^{2}$ political situation in Cyprus and determine the obstacles hindering their dream for a reunited island. The Triggering Question used in the previous (summer 2006) study $^{3}$ was "What factors contribute to the increasing gap between the two communities in Cyprus?" A group of 26 participants invested a total of $218 \mathrm{~h}$ person-hours to generate 120 factors, which they clustered under 20 categories. The structuring of 20 factors revealed that (1) the negative and provocative statements made by the media and the politicians, (2) the disempowerment of civil society as well as (3) the personal interests of those in power were among the most influential root causes and/or obstacles. The structured dialogue process supported the participants to create a shared understanding of the problematic situation. Empowered to commit to additional activities, they agreed to organize a follow-up co-laboratory in which to explore options which could enhance the social dialogue between the two communities. For the co-laboratory reported here they used the Triggering Question "What goals if achieved, would contribute significantly to bridging the gap between the two communities?" They also submitted an application as a joint consortium of six NGOs to request funding from UNDP to organize further co-laboratories (For a complete review of all bicommunal projects funded by UN, refer to UNDP and UNOPS websites in the references). The participants and domains of these future co-laboratories were to be decided depending on the outcomes of the co-laboratory in which they would explore options (i.e., the co-laboratory reported here) to enhance dialogue between the two communities. In other words, the aims of the co-laboratory reported here were to (a) produce a list of options/goals, which could potentially enhance social dialogue between the two communities; (b) structure the options/goals in the form of an influence map in order to be able to decide with some confidence which options/goals should be given priority; and (c) empower the participants to become actively involved in the organization of jointly agreed activities.

By the time of publication, many things have changed on the island. First, the elections in the South brought Mr. Demetris Christofias, General Secretary of the left party AKEL to power. Mr. Christofias' electoral program placed enormous emphasis on re-launching the peace process. Mr. Talat, in the North, remained committed to continue the negotiations based on the principles of the Annan Plan which was supported by the great majority of his people. Moreover, Mr. Christofias emphasized the fact that the solution must be found "by Cypriots for Cypriots." He thus embraced the position promoted for years by peace groups that Cypriots must assume responsibility in designing their own futures (Laouris and Anastasiou 1998). The active engagement of the stakeholders is also a key concept of the science of the structured dialogic design process. It is scientifically grounded through the law of requisite action (for discussion refer to Laouris et al. 2008, 2009), which states that

Footnote 1 continued

(Broome 1998) that served as their work's roadmap for the next couple of years. In the summer of 1995, the CRTG opened up to the community and invited more people to join. Hundreds of Cypriots participated in conflict resolution structured dialog workshops. No formal funding was available for these activities. One should recognize Fulbright and its Executive Director Mr. Daniel Hadjittofis for their strategic and logistical support. By the end of 1997, more than 2000 individuals were introduced to structured dialogue and had the opportunity to meet and discuss with members of the other community. For the historical map of all bicommunal groups created through their activities between 1993 and 1999 refer to Laouris and Laouri (2008) or Laouris et al. (2009).

2 The word "current" refers to the specified period.

3 The results of this previous co-laboratory were reported in Laouris et al. (2009). 
without the authentic, sincere and true engagement of the stakeholders any dialogue is bound to fail. Thus, from a scientific point of view, the failure of the final version 5 of the Annan $\mathrm{Plan}^{4}$ (which was prepared without the authentic engagement of Cypriots) should not come as a surprise. On the contrary, one could argue that the chances to reach an agreed settlement would be much higher if Mr. Christofias' current approach manages to engage Cypriots authentically (either through technical committees and/or through civil society dialogue opportunities such as the ones described here).

Second, the Greek Cypriot side lost its winner's monopoly at the European court. To this point, all cases sent to European court resulted in judgments in favor of GCs. A few new judgments related to property issues (e.g., Tymvios case 2003; refer to the section 'Discussion' for more details) complicate enormously the whole situation.

Third, the Civil Society Dialogue project (the results of which are partly reported here and in Laouris et al. 2009; see also Civil Society Dialogue in references) has been successfully completed in June 2008. The results of all activities taking place during the lifetime of the project were continuously publicized through mailing lists and through quarterly reports to UNDP. The scientific analysis and publication of the results follows with some time lag. The authors consider that the project contributed in many and diverse ways: (a) A few hundred Cypriots had the opportunity to participate in democratic dialogue sessions to discuss and explore problems of their concern; (b) The UN could exploit the collective wisdom of many local stakeholders to feed its own working groups when considering funding priorities; (c) Structured dialogue was promoted widely; and finally (d) The participants of the various co-laboratories taken together served as a Cyprus-wide Think Tank, which fed the political leadership and other relevant stakeholders with ideas that were carefully filtered, explored and structured.

\section{Method}

The participants were first acquainted and had the opportunity to reflect and discuss the results of the previous co-laboratory, which focused on defining the factors that contribute to the perceived widening of the gap between the two communities (published in Laouris et al. 2009). Most of them did not participate in the previous co-laboratory.

\section{The SDDP Method}

This co-laboratory was implemented using the Structured Dialogic Design Process (SDDP) methodology. An SDDP co-laboratory is specifically designed to assist inhomogeneous groups of stakeholders to deal with complex issues in a reasonably limited amount of time (Banathy 1996; Warfield and Cardenas 1994; For the theoretical grounding and examples on how time to resolve complex issues can be shorten using modern virtual communication technologies refer to Laouris and Christakis 2007; Laouris and Michaelides 2007; Laouris et al. 2007). It enables the integration of contributions from individuals with diverse views, backgrounds and perspectives through a process that is structured, inclusive and collaborative (for a complete review of the methodology see Christakis and Bausch 2006;

\footnotetext{
$\overline{4}$ It might be relevant to note that Cypriot peace builders participated and contributed in earlier versions of the Annan Plan.
} 
Schreibman and Christakis 2007). The SDDP methodology was chosen over other options for the following reasons. (a), the authors and some of the participants have participated in the "Peace Revival Project" some months earlier, which was implemented using the same methodology. (b) Most participants and members of the Knowledge Management Team (KMT) have extensive experience in the method as they have used it in many other analogous forums to facilitate organizational and social change. (c) An earlier version of the method, known as Interactive Management has been used extensively by the CRTG between 1994 and 1997 (Broome 2001, 2005; Laouris 2004) to address very similar issues. It would therefore be interesting to make certain comparisons between the results of previous co-laboratories and this one. (d) The SDDP promotes focused communication among the participants in the design process and results in shared ownership and commitment and convergence to an agreed-upon consensual action plan. It was therefore hypothesized that the process could serve as an inspiration to take action. Finally, (e) an SDDP co-laboratory provides an excellent opportunity for stakeholders, to not only expand their shared understanding of the current problématique, but also to develop a roadmap for their future work and achieve a consensus as to how to move forward. We therefore anticipated that the co-laboratory could contribute to the creation of this roadmap.

The Triggering Question for this study was "What goals if achieved, would contribute significantly to bridging the gap between the two communities?" The aims of the CRTG in their equivalent co-laboratory that took place in 1995 included: (1) To identify options for accomplishing the goals of our peace-building efforts in Cyprus. (2) To develop an alternative "options profile" of selected activities and recommendations that could be implemented during the next 12 months. (3) To formulate specific plans for the implementation of actions and recommendations. (4) To build our group into a strong force for bringing about change in Cyprus.

The co-laboratory took place at Platres, in an isolated resort hotel (Forest Park) in the Troodos Mountains of Cyprus.

Knowledge Management Team, Authors and Participants

The authors of this communication were also members of the Knowledge Management Team (KMT). The KMT had an additional four international members who are not authors in this paper. Two of the authors (2nd and 4th) were participants of the dialogue, i.e., contributed ideas, participated in the clustering and the structuring phases of the SDDP. Four of the authors (1st, 3rd, 5th and 6th) served as facilitators. Thus, this paper reflects a consensus of interpretations of the results among members of the KMT, the facilitators and representatives of participants. Out of the 20 (12 TCs and 8 GCs) participants of this colaboratory, nine (5 TCs and 4 GCs) have also participated in the previous (which explored obstacles; Laouris et al. 2009). The report from the co-laboratory, along with the first draft of the paper, has been sent to all participants for contributions. This final version includes comments, interpretations and ideas from practically all participants.

\section{Indices of Complexity, Spreadthink and the Erroneous Priorities Effect}

Scientific measures were applied in order to enable objective comparisons between the data collected in this co-laboratory with (a) the previous co-Laboratory that explored obstacles (Laouris et al. 2009) and (b) analogous co-laboratories organized in 1995.

The complexity index defined as $\mathrm{SCI}=\mathrm{DK}(N-7) / R(R-1)$ 
$V=$ Number of ideas receiving 1 or more Votes $N=$ The number of ideas

$K=$ The number of connections in the map; $R=$ The number of Ideas in the map $D=(V-5) /(N-5)$

The Spreadthink defined: ST $=(V-5) /(N-5) \times 100$ (Warfield 1995; modifications were made by the last author of this paper)

The Erroneous Priorities Effect (EPE) discovered by Dye in 1999 (Dye and Conaway 1999) refers to the fact that individual importance preferences on factors relevant to the problem situation voted on prior to relational inquiry among the factors may prove to be "erroneous," if at the end they are collectively judged to not be the most influential. It can be demonstrated by calculating the cumulative influence of the most influential factors and compare it with the influence of those factors that received most votes of relative importance.

\section{Results}

The Structured Dialogic Design Process (SDDP) is a rigorously validated methodology, which has the capacity to integrate knowledge from mixed participants in strategic design settings. It is especially effective in resolving multiple conflicts of purpose and values and in generating consensus. The SDDP normally operates by first looking for obstacles using an appropriate triggering question and subsequently explores goals through a different triggering question. In the previous co-laboratory (Laouris et al. 2009) half of those who participated in the current co-laboratory together with selected peace pioneers examined the perceived obstacles that contribute to the increasing gap between the two communities in Cyprus. In this co-laboratory, participants were encouraged to explore options/goals which, if achieved, could contribute significantly to bridging the gap between the two communities. The results reported below and in the section "Discussion" demonstrate how the obstacle definition phase supports participants come up with better actions and how the options' phase empowers them to reach consensus and move forward and implement what they have agreed. Figure 3 illustrates the fact that the previous co-laboratory, which aimed to identify obstacles that contribute to the increasing gap between the two communities in Cyprus, supported participants to come up with more effective actions to deal with those obstacles (refer to the section "Discussion"). The current co-laboratory (also referred to as options' co-Lab), empowered participants to envision and implement practical projects and actions with the aim to change the problematic situation. The authentic and true engagement of relevant stakeholders in the follow-up activities (refer to section "The road ahead") guaranteed the successful outcome (as predicted by the Law of Requisite Action; Laouris et al. 2008, 2009).

The results, reported and discussed below, were collected during a two-day co-laboratory, which was organized at Platres, Cyprus between March 10 and 11, 2007. The process required $10 \mathrm{~h}$ of collaborative work, which resulted to a total of 200 person-hours (excluding follow up analysis, interpretations and report generation). During the 2-day event the participants came up with 83 factors, which were clustered in 13 categories. Twelve factors were structured during the co-laboratory to create an influence map which was then publicized as a report and sent to all participants and interested stakeholders immediately following the event, while 15 additional factors were structured a few weeks later. All reports were made available also on line at the project's website (http:// www.civilsocietydialogue.net). 
Composition of the Group

The participants were 20 Cypriots. Eight were GCs and twelve were TCs. Nine (5 TCs and $4 \mathrm{GCs}$ ) have also participated in the previous co-laboratory (which explored obstacles; Laouris et al. 2009). The 11 new participants were chosen based on two criteria: (a) to represent different types of stakeholders and (b) to have a clear history of interest and ability to take action and implement projects. Fifteen participants had relevant experience and have contributed significantly to the Cyprus peace process in earlier years. Two of the participants (one is the 4th author) and two of the facilitators (1st and 3rd authors) were members of the CRTG. More than half of the participants had experience with the SDDP methodology; some have previously facilitated SDDP sessions. Three participants are academically active and have published their own ideas and research results about the Cyprus problem. Five participants are business people, five are in education and the rest are active in civil society. Eight are female and 12 are male. Ten were 40-55 years of age and ten were 25-40 years. The last author of this report headed the international wing of the KMT, which consisted of international experts (Acknowledgements) and one Cypriot youth (7th author). The KMT remained constant and active throughout the process and supervised all activities.

\section{Options to Enhance Social Dialogue}

Table 1 documents 44 out of the 83 factors proposed by the group as potential goals that could enhance social dialogue between the TC and GC communities in Cyprus. The participants spent $2 \mathrm{~h}$ to clarify their proposals. In this paper, we do not provide the actual clarifications, but only the "headings" of the participants' suggestions. The participants clustered the 83 factors in 13 categories as shown in Fig 1. Following this phase, each participant was requested to choose his/her five favorite factors. The voting results were used to select factors for the subsequent structuring phase. Optimally, all factors receiving votes must be structured. With 44 factors receiving votes, the Spreadthink was $50 \%$, i.e., the level of disagreement among the participants is slightly higher than the expected average of $40 \%$ (especially when one considers the fact that participants have similar political views). During the next few hours, the participants managed to structure 12 factors. The KMT scheduled later a voluntary meeting to structure additional factors. In order to ensure that the resulting tree of the influence map would be as comprehensive as possible and would address all perspectives, the KMT applied scientifically grounded rules to select 15 additional factors. The guideline was based on two rules: (a) to ensure that, if possible, all clusters were represented; (b) to choose factors which experienced participants would consider as possible root-drivers, i.e., they chose factors which had the possibility to appear in the deeper layers of the map.

\section{The Root Drivers Map}

The following diagram (Fig. 2) shows the influence map as it was completed after the twoday co-laboratory. Twelve factors were structured within five layers. The Situational Complexity Index was 14.39. Figure 3 documents the influence map after an additional 15 factors were structured a few weeks later. Twenty-seven factors were structured within six layers. With the additional factors in the map, the Situational Complexity Index dropped to 10.88. The interpretation of the results is done in the section "Discussion". 
Table 1 Documentation of the 44 ideas that received 1 or more votes

\section{No. Votes Goal}

98

426

25

45

155

14

54

194

264

103

343

353

32

132

182

$28 \quad 2$

302

392

462

492

502

532

592

652

$8 \quad 1$

121

$17 \quad 1$

201

231

$24 \quad 1$

$31 \quad 1$

321

361

$44 \quad 1$

521

551

561

$57 \quad 1$

601

621

$64 \quad 1$
Accomplishing island wide free trade and economic integration creating inter-dependence Teach Turkish \& Greek as an obligatory second language at schools

Increase awareness of benefits of a more unified island

To have more positive and independent media on both sides

Make possible for the TC to use rights arising from the Cyprus constitution and EU membership

Develop common business ventures, especially in services

Transforming the buffer zone into a zone of cooperation and joint projects

Investigate, document and publish the truth behind the events since the $50 \mathrm{~s}$

Develop a culture of political correctness

Adoption of the Turkish language as a working language of ROC

Establishment of a genuinely independent multicultural educational institution in all levels

Promote modern diplomacy methods by making zero sum VS win-win concepts widely known

Establishment of a reconciliation committee in the context of the Gambari process

Ostracise nationalism

Create a common civil society platform

A common venture capital fund for joint economic initiatives

Create a climate for apology, empathy and forgiveness

Utilize polling to contribute to the peace process similar to the Northern Ireland experience

Adoption of Euro island wide

Make people realize that no solution is not in their interest

Unconditional returning of Varosha to its original owners under the ROC administration

Decrease the Turkish Cypriot dependency on Turkey

Education systems should promote cooperation

Design common history text books and other common educational material and teacher training

Create sustainable incentives in crossing and cross-border activities

Create a mechanism for the indigenious TC to take their destiny in their hands

Create environments (TV, newspaper, radio) for journalists to collaborate

Show similarities of the two communities through the media, especially TV

Penetrating in the mainstream media of the 'other side'

The demilitarization of Nicosia

Increase bi-communal contacts between different social groups

A revolution in system of values, behavioral patterns and perceptions of individuals

Getting the technical committees up and running efficiently

Professionalise the NGO sector

Create opportunities for students and citizens to learn about human rights and their complexity

Make the status quo uncomfortable without driving the other side away

Increase the awareness and knowledge of the ordinary people on the successful models of Governance based on power sharing

Create a common monument for the victims of both sides

Expand the scope of the Green Line Regulation and increase the number of gates

Start discussion in civil society of what sort of solution we want

Full geographic survey of the whole island and include land issues in the workings of the future Reconciliation committee 
Table 1 continued

\begin{tabular}{|c|c|c|}
\hline No. & Votes & Goal \\
\hline 73 & 1 & $\begin{array}{l}\text { Use structured methodology to construct a comprehensive plan for the settlement of the Cyprus } \\
\text { problem }\end{array}$ \\
\hline 74 & 1 & Adoption of Turkish as an official language of the EU \\
\hline 79 & 1 & Put pressure on the EU not to tackle the Cyprus conflict as a derivative of Turkey-EU process \\
\hline
\end{tabular}

\section{Discussion}

\section{A Clarification Regarding the "Authenticity" of Ideas}

For the reader who is not familiar with SDDP, it is necessary to make the following clarification. The Law of Requisite Autonomy (Tsivacou 1997) requires the facilitator(s) to protect the autonomy and the authenticity of every participant. It is therefore imperative that the statements offered by the participants are 'read' having always in mind that they reflect individual perceptions. Others may ask for clarifications, but they are not allowed to make value judgments or request re-wording. For more details on this issue, please refer to the discussion of our previous publication (Laouris et al. 2009).

\section{Reflecting on the Breadth and Depth of Ideas, Complexity and the Erroneous Priority Effect}

The participants came up with 83 factors, which could possibly contribute to the enhancement of social dialogue between their conflicting communities. The number is similar, compared to the analogous co-laboratories implemented 12 years earlier in 1995. For example, in two analogous workshops, which took place in separate settings for GCs and TCs in 1995 with a similar triggering question and a similar composition in participants, the number of factors generated was 72 for the GCs and 101 for the TCs. The peace process revival co-laboratory that preceded this one produced 120 ideas. It is probably interesting to note that the participants were able to identify more obstacles than solutions, possibly an expression of their luck of hope. The average number of observations to adequately describe a complex social problem is 64 (Warfield 1988, 2009).

The factors were clustered in 13 distinct categories (Fig. 1). These categories covered issues across a wide spectrum, ranging from practical (e.g., economic integration, NGO sector, truth and reconciliation committees, buffer zone); empowerment (empowerment of TCs, youth etc.); political (politicians, political correctness, track I trust building) to technical logistical (e.g., application of modern methods, structured dialogue, research and recording). It is worth noting that the number of clusters generated for this study, as well as for the previous completed "Peace Revival Process" co-laboratory (Laouris et al. 2009) is higher than the number of clusters of the two 1995 studies (refer to the comparisons in Table 2). The Spreadthink was $50 \%$, which is a sign that the level of agreement between the participants is actually less than one would have expected. It is interesting that in the analogous 1995 settings the Spreadthink was 29 and $28 \%$ for GC and TC, respectively. For the "Peace Revival" co-laboratory the Spreadthink was also 50\%. Thus, 12 years earlier, we observe a much higher "agreement" both among GCs and TCs. The fact that the 

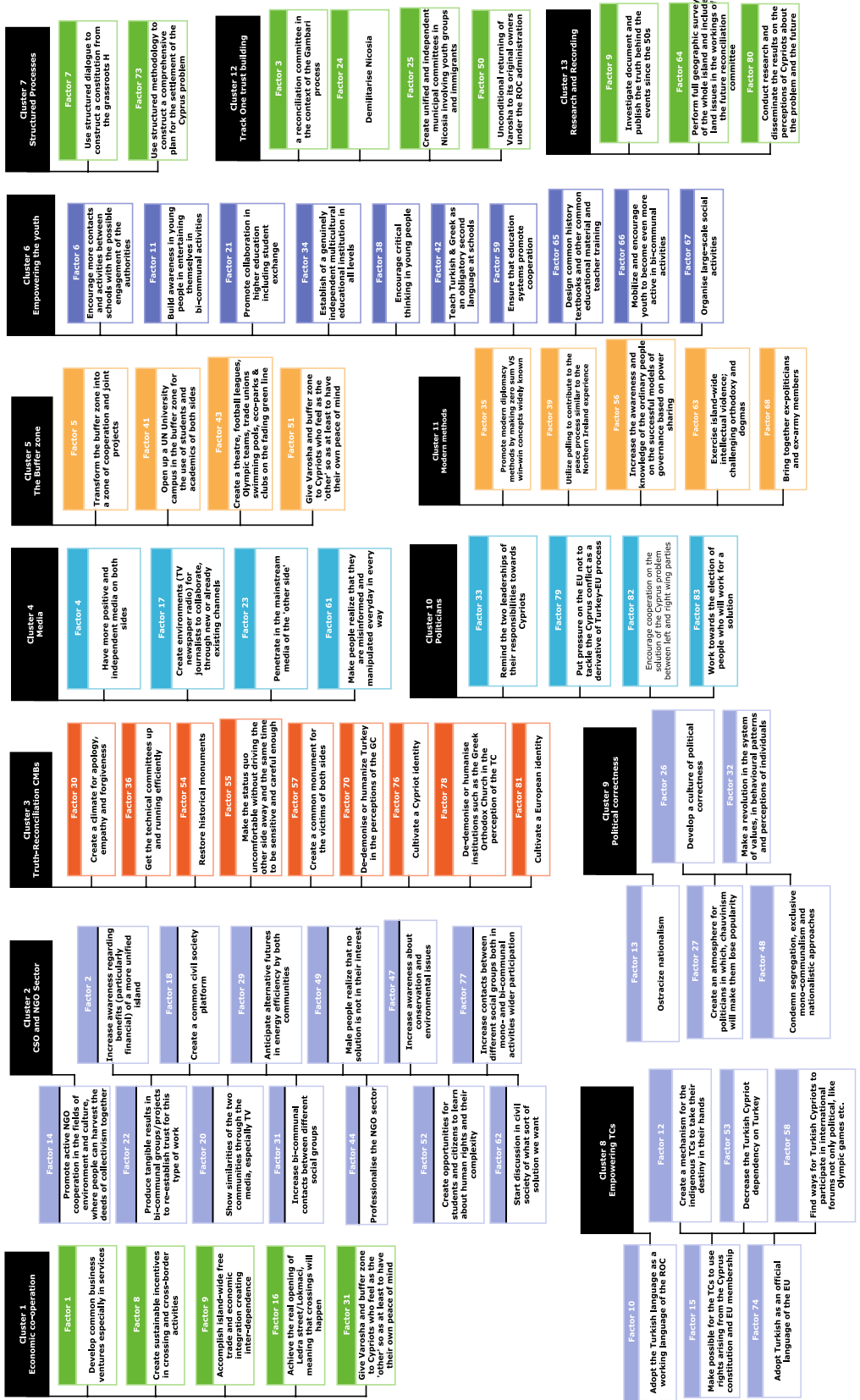

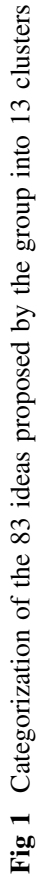




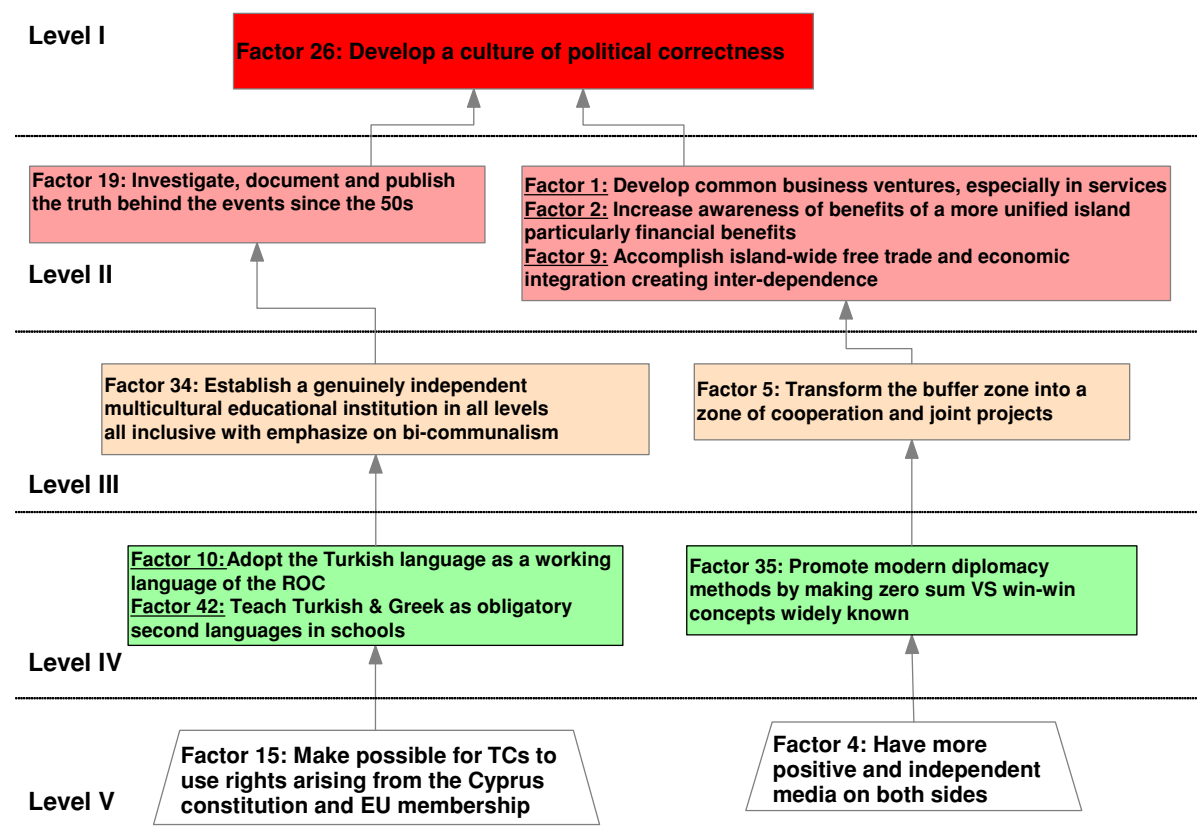

Fig. 2 The influence map with only 12 factors structured. The factors spread over 5 layers. SCI $=14.39$. Factors at the root of the influence map are considered most influential

Spreadthink of the current studies (both this and the previous) is higher than both 1995 studies should alarm us that the participants share a great degree of disagreement between them. This is especially worrying if one also takes into account that the participants were a relatively homogeneous group of peace builders. The Situational Complexity Index (SCI) is a measure that can give us an idea of how complex is a specific problem (as perceived by the participants). In our case, there is also value in comparing indices with those of analogous co-laboratories that took place in 1995, as well as with the previous co-laboratory, which focused on obstacles. CSI was 7.11 and 10.6 for the 1995 co-Laboratories (Table 2), 22.9 for the Obstacles' co-Laboratory and 10.88 for the current one. This can be interpreted as follows: SCI does not appear to have changed since 1995. Participants perceive the complexity of dealing with obstacles as higher (22.9) compared to defining options. It is also worth noting that SCI dropped from 14.39 (Fig. 2) to 10.88 (Fig. 3) when participants structured more ideas.

Factors 73 and 8 have received only one vote each. Yet, when the participants were asked to evaluate them with respect to their "power to drive" the system towards an optimal state (here for example an optimal state would be appropriately described by factors at the top of the map such as "develop a culture of political correctness"), they collectively decided that these two factors are most influential. This is an excellent demonstration of the erroneous priority effect. If participants were to agree on actions based on the number of votes that factors have received before the structuring phase that produced the map, they would have chosen factors 9 and 42 which received 8 and 6 votes, respectively. Interestingly, they lay in levels II and III, respectively, thus being less influential. 


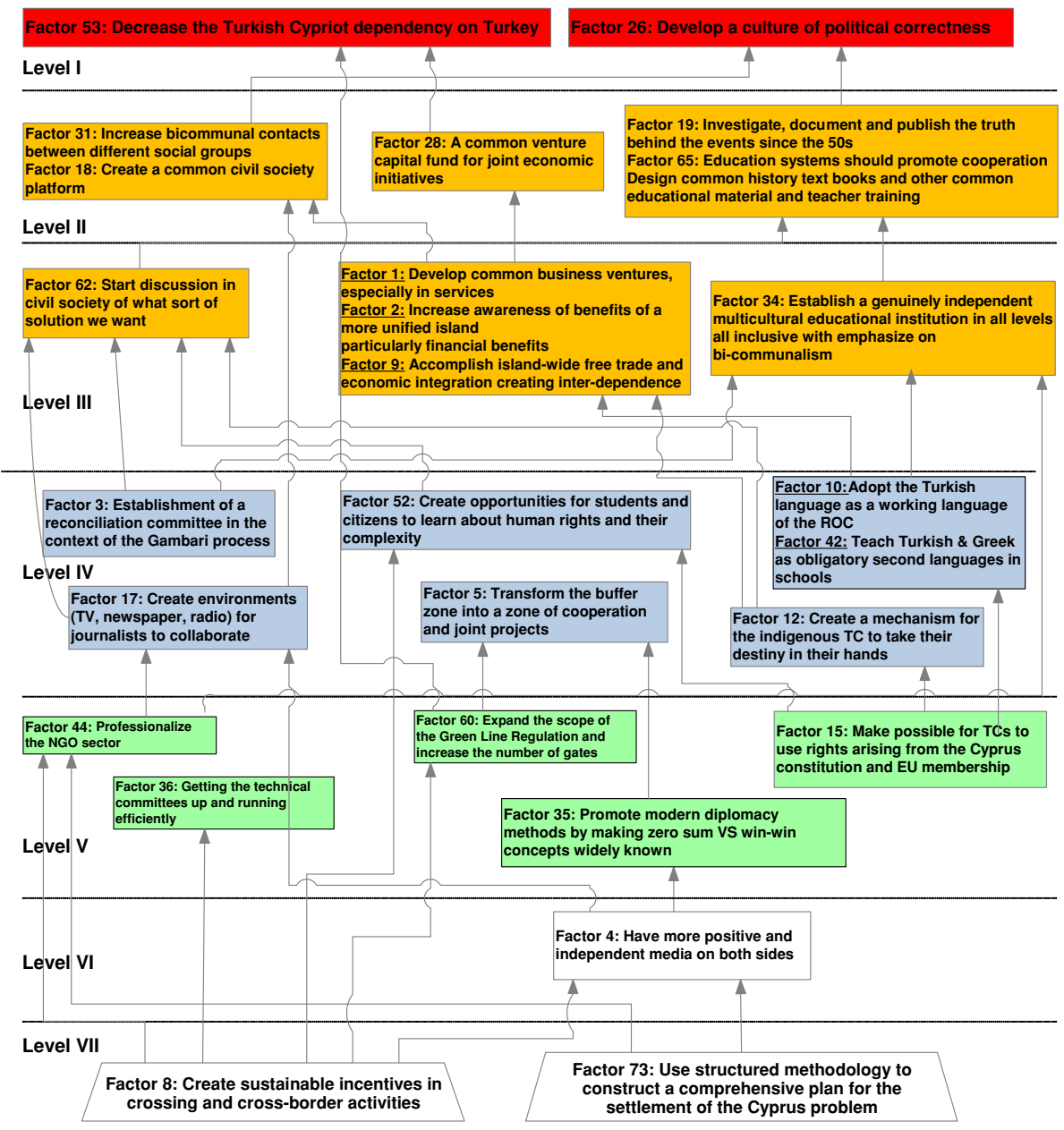

Fig. 3 The influence map with 27 factors structured. The map became richer, factors spread over 6 layers and complexity, SCI, fall to 10.88

Deep Drives and Influences

\section{Discussion of Layer 7}

There are two dominating deep drives in Layer 7:

Goal 8: create sustainable incentives in crossing and cross-border activities

Goal 73: use structured methodology to construct a comprehensive plan for the settlement of the Cyprus problem

Following the partial opening of several "Gates" starting with the one at Ledra Palace which opened on April 23, 2003, many Cypriots have crossed to the "other" side. According to an EU report (Annual Report on the implementation of: Council Regulation $866 / 2004) 788,823$ GCs crossed from the government controlled areas to the northern part 
Table 2 Comparison of scientific descriptors of different co-laboratories

\begin{tabular}{|c|c|c|c|c|c|c|c|c|}
\hline Workshop title & Year & $\begin{array}{l}N \text { no. of } \\
\text { factors } \\
\text { generated }\end{array}$ & $\begin{array}{l}\text { No. of } \\
\text { clusters }\end{array}$ & $\begin{array}{l}V \text { no. of } \\
\text { factors with } \\
>1 \text { votes }\end{array}$ & $\begin{array}{l}R \text { no. of } \\
\text { factors } \\
\text { structured }\end{array}$ & $\begin{array}{l}\text { No. of } \\
\text { layers in } \\
\text { the map }\end{array}$ & CSI & $\begin{array}{l}\text { Spreadthink } \\
\text { ST }(\%)\end{array}$ \\
\hline $\begin{array}{l}\text { Options to peace- } \\
\text { building (GC's) }\end{array}$ & 1995 & 72 & 10 & 25 & 25 & 9 & 7.11 & 30 \\
\hline $\begin{array}{l}\text { Options to peace- } \\
\text { building (TC's) }\end{array}$ & 1995 & 101 & 9 & 36 & 36 & 11 & 10.6 & 28 \\
\hline Peace process revival & 2006 & 120 & 20 & 60 & 20 & 7 & 22.9 & 50 \\
\hline Options to dialogue & 2007 & 83 & 13 & 44 & 27 & 7 & 10.88 & 50 \\
\hline
\end{tabular}

The table compares the total number of ideas generated; the number of clusters, the number of factors that received votes, the number of factors structured, the number of layers in the map the Situational Complexity Index (CSI) and the Spreadthink (ST) of this co-Laboratory with (a) two analogous ones that took place in 1995 and had very similar triggering questions and (b) the preceding co-laboratory which dealt with the problématique. Please refer to the text for interpretation of the data

of Cyprus and 1,348,215 TCs crossed to the south between 1 May 2006 and 30 April 2007. The reader should note that the population of GCs is about five times higher as that of TCs. In the first 6 months of this period, in total 812,756 TCs crossed, in the second half of the period this number fell to 535,459 , a decrease of more than $30 \%$. The number of GCs crossing remained low since the opening of the gates. GCs crossing are mainly those who were displaced in 1974 and their families. In sum, it is rather obvious that despite the opening of the "gates" the interest to cross is in general low, and it is almost negligible for GCs. Therefore, according to the participants of this co-laboratory, it is necessary to create sustainable incentives in crossing and in cross-border activities. It might also be relevant to remind that during Mr. Papadopoulos' presidency those crossing were stigmatized and portrayed with negative colors in the media. The section regarding the "Green Line Regulation" below extends this discussion on the economic aspects of crossing.

It is not surprising that the participants have "voted" the use of structured methodologies as most influential. They go so far to suggest the application of the SDDP methodology for the construction of a comprehensive plan for the settlement of the Cyprus problem. This should not come to a surprise as more than half of them have extensive positive experiences from numerous applications of the SDDP. The participants have made their report public to all authorities. Furthermore, the authors have agreed to send a complete information package about the SDDP including relevant publications to the leaders of all political parties and to the negotiators. Finally, the participants agreed to organize SDDP trainings and also to use the SDDP to implement a number of co-laboratories (see the section "The Road Ahead").

In the remainder of this section we also discuss the deep drivers in layers VI, V and IV.

\section{Discussion of Layer 6}

Layer 6 is dominated by only one factor.

Goal 4: To have more positive and independent media on both sides

The unconstructive role of the media is a factor that made it to the very bottom of the GC's root-cause map in their 1995 co-laboratory (Refer to Factor 36: Existence of an adversarial culture proliferated by the mass media; see Appendix I in Laouris et al. 2008 or 
Broome 1998). According to Broome's summary (1998), "until these obstacles are adequately addressed, the participants perceive that it will be very difficult to promote effective peace-building efforts in Cyprus." It is disappointing that 11 years later (19952006), the "Peace Revival Project" also diagnosed the same problem (Refer to Factor 72: Media as puppets of the political parties; see the map in Fig 3 in Laouris et al. 2009). In the years that followed, peace builders have pioneered many interventions to the world of the media. As early as 2000, a group of young peace pioneers widely known as Youth Promoting Peace ${ }^{5}$ with a grant from UNDP of only 2,300 CYP (under €4,000) produced a 1-h bicommunal film called "Skies Onirou: Shadows of a dream". For the production they relied on voluntary support and personal contacts. In contrast, an enormous investment went to the production of a series of television programs in the UK called Gimme6. It tells the story of five children from different backgrounds that meet one summer in the UK while exploring an abandoned theatre. The eight episodes follow their adventures as they learn to work as a team within an international, multicultural environment. It was broadcast by television channels in both communities and used in educational contexts; its quality was widely acknowledged. Nevertheless it was also criticized as very much a top-down production, requiring enormous resources with uncertain outcome and benefits.

More conventional ICT projects running from 2001 to 2004 included the www.Tech4Peace.org ${ }^{6}$ portal, E-voices Cyprus and the Cyprus MediaNet bicommunal newspaper. The Tech4Peace portal equipped pioneer peace builders of the nineties with information and technology tools that they could use in their peace work. The implementing team offered free training to a few dozen NGOs, aimed at indirectly supporting their activities by introducing an information technology dimension to their work. The portal is trilingual with information available in Greek, Turkish and English. Crackers have repetitively attacked the portal. It has also been repetitively target of nationalistic media both on the island and in Turkey (see articles about DOGAN and also news in Simerini (2004) newspaper in the references attempting to accuse the project). E-voices Cyprus was $a$ bi-communal Internet forum in Greek, Turkish and English for civic expression and participation. It solicited public opinion and encouraged dialogue and debate in an inclusive, transparent, and democratic manner. Cyprus MediaNet was a website offering a selection of articles from print media across Cyprus translated into three languages, Greek, Turkish and English, in an attempt to encourage better mutual understanding and improved journalism. Although it functioned well, was accessed by a considerable number of people and was of high quality, it was discontinued some time after funding ran out in December 2004. The reason was that the media and the President accused its founder, Mr. Christos Stylianides that he used it to support the Annan Plan. In 2001, the Youth Centre in the North and the 1st author's organization (CNTI: Cyprus Neuroscience \& Technology Institute) in the South collaborated on a young journalists' project. Ten young journalists (five each side) were hosted by families in Washington DC. During their training program, they attended special seminars concerning deontology, professionalism, and objectivity. They also had the opportunity to visit the various libraries where they could perform some research and improve their English language skills. Upon returning to the island, they collaborated for almost a year. Some of them advanced in their careers and hold important positions from where they are able to promote rapprochement.

\footnotetext{
5 Youth Promoting Peace was a group of about 15 youth pioneers facilitated by the 1 st author of this paper, whose organization provided logistical and financial support.

6 The Tech4Peace project has been implemented by the 1st and 3rd authors' organization.
} 
A closed-door journalists' conference that took place in the summer of 2002 was instrumental to the diagnosis of the problem. It addressed ethics and roles of mass media in Cyprus. It was organized by CNTI and hosted at Intercollege. Mr. Marios Karoyian (President's Papadopoulos spokesman at the time and President of the Democratic Party at the time of preparation of this article) underlined the importance of the issue. The questions dealt were: (1) Are journalists free to cover news or do they "serve" their employers? (2) Are journalists obliged to promote social justice and respect human integrity or to merely "reflect" the real world? Unfortunately, the results were rather negative. Following eight hours of deliberations their answer to both questions was "no." I an attempt to address the negative situation, the Management Centre in the North together with the CNTI in the South organized between 2003 and 2005 six media literacy workshops with funding from a small American NGO (Hasna.org).

In March of 2004, 'BIZ-E $\mu \varepsilon i \varsigma$ ' started. It is a 60-min daily TV show, broadcast at 7 p.m. every afternoon at $\mathrm{CyBC} 2$. The aim is to cover topics that are interesting for both communities. It is broadcasted both in Greek and Turkish, aiming to strengthen the bicommunal spirit and cooperation. The show includes interviews, invites guests into the studio, presentations on specific themes, reportages with movie productions in both communities etc. It continues into the present.

In 2005, a live tri-lingual bicommunal radio program called Talk of the Island was started which currently continues through funding from an American NGO (HasNa). This was a project run by CNTI and Management Centre. In 2006, USIP funded the installation of telephone lines for "Talk of the Island" that made it possible to use any studio and allow Cypriots from both sides to call in as if the studio were on their side (thus removing psychological obstacles).

The organization of the "Peace Revival" co-laboratory in the summer of 2006 highlighted the fact that the media remain a significant contributor to the negative climate. Important factors proposed included: (a) Have a more positive and independent media on both sides; (b) Show similarities of the two communities through the media, especially TV; (c) Penetrate in the mainstream media of the 'other side'; (d) Create environments (TV, newspaper, radio) for journalists to collaborate, through new or already existing channels; (e) Penetrate in the mainstream media of the 'other side'; (f) Make people realize that they are misinformed and manipulated everyday in every way. The participants also suggested that a future workshop on the Media should be held to possibly develop a vision of how the media landscape in a future reunited and socially more developed Cyprus could appear.

In 2007, CNTI and HasNa teamed up again to initiate the "New Media Landscape Now!" project. The parties agreed to work together to promote collaboration in Cyprus with aims to bring together journalists from both sides of divided Cyprus to produce a strong vision for an ideal media landscape which would hopefully serve as a magnet to mobilize a chain of transformation.

This review is probably incomplete. Many projects address the media culture, broadcasting, telephony and Internet. Even though comprehensive evaluations are not available, it is safe to state that a lot more work is needed. Nevertheless, funding and sustainability appears to be a difficult goal to achieve. The determination of impact is another difficult area. However, in sum, the above discussion underlines the fact that the media landscape in Cyprus could still benefit from some creative restructuring and renewal. At the time of preparation of this article, the UNDP has taken an important initiative. They have informed civil society about their readiness to support the creation of an independent media center. As a result, representatives of eight NGOs formed a Steering Committee to work on this. 
Two members of our team (one is the 6th author of this paper) prepared a business plan to explore the feasibility of such a venture for the consideration of the NGO's committee.

\section{Discussion of Layer 5}

Layer 5 is very rich with ideas.

Goal 44: professionalize the NGO sector

Goal 36: getting the technical committees up and running efficiently

Goal 60: expand the scope of the Green Line Regulation and increase the number of gates

Goal 35: promote modern diplomacy methods by making zero sum vs win-win concepts widely known

Goal 15: make possible for the TC to use rights arising from the Cyprus constitution and EU membership

About NGO Life in Cyprus The non-partisan, non-governmental sector, as well as the concept of volunteerism, is not well developed in Cyprus. Except for philanthropic and hobby-related organizations, NGO life in Cyprus is less than 10 year old. The unquestionable power of the political parties in connection with the strong polarization within society does not leave a lot of space for an independent civil society to thrive. On another angle, almost all European member states take advantage of the program known as EVS (European Voluntary Service), except Cyprus. The EVS funds organizations to send individuals to volunteer in NGOs in another member State. Cyprus has no sending and no receiving NGOs yet.

Technical Committees On July 8, 2006, the United Nations facilitated the signing of an agreement between President of the Republic of Cyprus Tassos Papadopoulos and Turkish Cypriot leader Mehmet Ali Talat relating to the reunification of Cyprus. According to the agreement, technical committees and working groups would be set up to examine and discuss issues that affect day-to-day life of the people of Cyprus and concurrently those that concern substantive issues, thus contributing to a comprehensive settlement of the Cyprus problem. Unfortunately, the technical committees were never launched until the government in the Republic of the Cyprus had changed. The newly elected Greek Cypriot president, Demetris Christofias, and the Turkish Cypriot leader, Mehmet Ali Talat, agreed on 21 March, 2008 to launch the Technical Committees and working groups. On Friday, 18 April, 2008 the heads of the committees and groups started their work: six working groups and seven technical committees were founded. Working groups focus on "Administration and Division of Power", "EU Affairs", "Security", "Property" and "Economic Affairs". Technical committees work on "Crime", "Trade Issues", "Cultural Heritage", "Crisis Management", "Humanitarian Issues", "Health" and "Environment". At the time of preparation of this article, the technical committees have met and have prepared the ground for meetings between the leaders. At the time of publication, even though no significant progress has become evident to the people of Cyprus, the two leaders launched direct meetings to discuss difficult issues and issues in which no agreement has been reached in the committees. Their approach of addressing sub-problems of the problem might however not prove successful; the solution of a complex problem requires systemic tools and adherence to the laws of the science of dialogic design. 
The "Green Line Regulation" The Green Line Regulation entered into force on 1 May, 2004. It defines the terms under which the provisions of EU law apply to the line between the areas of the Republic of Cyprus. The Government of the Republic of Cyprus exercises effective control in the areas in which the 'Green Line Rugulation' $(2004,2005)$ does not. On 10 August, 2004, the Commission adopted a new regulation laying down specific rules concerning goods arriving from the areas not under the effective control of the Government of Cyprus into the Governmental controlled areas. (Commission Regulation 2004). On 17 February 2005, the Council adopted amendments to the Green Line Regulation in regards to agriculture and facilities for persons crossing the line Green Line Regulation amendments 2005). On 18 April, 2005, the Commission adopted an adaptation to Annex I of the Green Line Regulation. Two additional crossing points have extended the list of crossing points: Ledra Street and Zodia. (Commission Regulation 2005). At the time of the co-laboratory reported here, the two additional crossing points were not opened. On April 3, 2008, the Ledra Street roadblock crossing through the UN buffer zone was reopened after 44 years. Until before the publication of this article, the Zodia crossing has not been opened. Moreover, since the Regulation has been in place, the volume and value of goods crossing the line remain limited. During the reporting period of 1 May, 2004 to 30 April, 2005 the total value of the goods, for which documents were issued, amounts to EUR 1,000,617.

In May, 2007, the EU made amendments to the 2004 agreement (Commission Regulation 2007) aiming to further facilitate trade and economic cooperation on the island and improve confidence and integration between the two communities. More specifically, they provided for the lifting of duties on agricultural products; they provide for an increase in the total maximum value of goods contained in personal luggage; and to govern the temporary introduction of goods from the northern part of Cyprus, where the Government of the Republic of Cyprus does not exercise effective control into the areas that are not under control of the Government. The duties on agricultural products originating in the North were lifted. Furthermore, (for up to 6 months), the temporary introduction of goods from the North, into the areas, into which the Government of the Republic of Cyprus exercises effective control, is regulated in a more transparent way. The leaders expect that this will encourage the provision of services across the Line, facilitate participation in trade fairs or similar events and also permit the repair of equipment in areas in which the Government of the Republic of Cyprus exercises effective control. Finally, the total value of goods contained in the personal luggage of persons crossing the Line is substantially increased from $135 €$ to $260 €$ so as to encourage economic interaction on the island.

\section{Promote Modern Diplomacy Methods by Making Zero Sum Versus Win Win Concepts} Widely Known The Cyprus problem has traditionally been discussed on the basis of zero sum models. Not only the politicians, but also society at large is unaware of the potential benefits that win-win approaches could bring to the island. The public discourse is dominated by adversarial diplomacy and we rarely encounter innovative ideas and solutions. Exceptions to this rule was President Vasilleiou's suggestion in the nineties to build a second city of Morphou next to the old one (thus duplicating options) or President Papadopoullos' idea expressed during the 2008 election period to give GCs "freely convertible construction rights" using as collateral their properties in the occupied zone. Unfortunately, these and a few other innovative ideas never received any serious consideration. The Cyprus Island could be transformed into a paradise if a solution focuses on ideas that can improve the economy and the life style on the island rather than killing time over endless disputes. 
On TC's Rights Arising from the Cyprus Republic Constitution and EU Membership In the case Aziz v Cyprus (2001) the European Court of Human Rights has decided in June 2004 that his application to the Minister of the Interior, requesting to be registered on the electoral roll in order to vote in the parliamentary elections of 27 May 2001 was legitimate. The Court noted that the applicant was a Cypriot national, residing in the Government-controlled area of Cyprus. It observed that the difference in treatment of which the applicant complained resulted from the fact that he was a Turkish Cypriot. It emanated from the constitutional provisions regulating the voting rights of members of the Greek-Cypriot and TurkishCypriot communities that had become impossible to implement in practice. The Court considered that this difference could not be justified on reasonable and objective grounds, particularly in the light of the fact that Turkish Cypriots in the applicant's situation were prevented from voting at any parliamentary election. On 26 April, 2006, Ali Erel and Mustafa Damdelen filed an analogous request to the Supreme Court of the Republic. In this case, they both live in the northern part of the island. The participants of this co-laboratory seem to agree that the leverage of the European Court of Human Rights could facilitate awareness regarding the fact that TC's do not enjoy all their rights as well.

In 1999, Mümtaz Soyzal, the Professor of Constitutional Law and Constitutional Adviser to the TC leader Rouf Denktash, argued that TCs have significant rights rising from the 1960 constitution which could be exploited to apply pressure for a solution (Soyzal 1999).

\section{Reflecting on the Ideas at the Top Layer of the Map}

Factors that make it to the top of the tree almost always reflect those goals most desired by the participants. In Level 1, we have Goal 53: Decrease the TC dependency on Turkey, and Goal 26: Develop a culture of political correctness. According to the collective wisdom of the participants, both these goals depend on making progress on all goals that lie below. It is obvious that Turkey controls almost every aspect of life in the northern part of the island. Yet, decreasing that influence is pertinent to actually solving the Cyprus problem. Therefore, it might serve as visionary destination, but one must search for intermediary milestones, which could facilitate gradual progress towards this end. Similarly, a culture of political correctness is a desired state, but it is not something that can be implemented or achieved through any single action or political decision. These findings may appear logical after the map has been constructed. However, before the structuring phase, the participants placed significant priority to these factors by giving four votes to factor 26 and two votes to factor 53 . The fact that the ideas that receive many votes originally, don't turn out to be very influential is also an expression of the erroneous priorities effect (Dye and Conaway 1999).

\section{The Road Ahead}

This co-laboratory has been organized in the context of the UNDP funded Civil Society Dialog project ${ }^{7}$ with the aim to define and decide areas of intervention. The results have been compiled and analyzed in several face-to-face and virtual ${ }^{8}$ meetings of the Steering Committee of the project. They fed the discussions and shaped the final decisions as to what actions should be taken to facilitate "revival" of the peace process within civil society.

\footnotetext{
7 www.civilsocietydialogue.net

8 The last author who is the Head of the KMT and member of the Steering Committee participated via telephone/video conferences.
} 


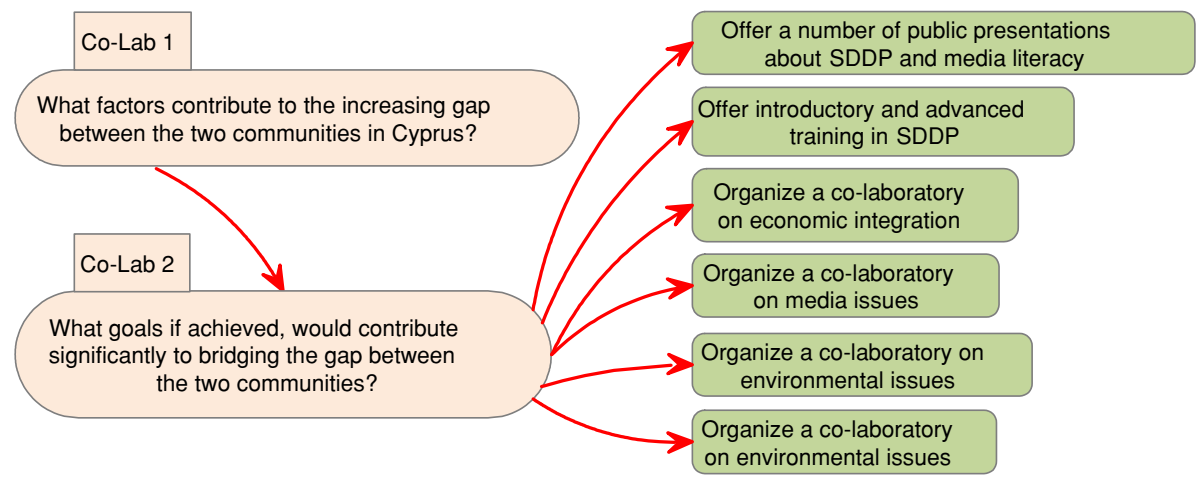

Fig. 4 Flow of events and co-laboratories. The diagram illustrates the flow of activities. Following co-Lab 1 which aimed to identify the obstacles that contribute to the increasing gap between the two communities in Cyprus, co-Lab 2 encouraged the participants to explore options. At the conclusion of co-Lab 2 the participants agreed on actions and projects

The following actions (Fig. 4) have been agreed: (1) Offer introductory and advanced training in the SDDP; (2) Pair newcomers to the process with senior members of the Cyprus Intercultural Training Initiative (CITI) community who are experts in the application of SDDP; (3) Organize a number of co-laboratories focused on the domains of media, economic integration, environment and others to be agreed upon based on the findings of the work described here and depending on momentary priorities; (4) Offer a number of public presentations about SDDP and media literacy. At the time of publication of this article the following actions have been completed:

- SDDPs were organized in the domains of media, economic integration and reunification of Famagusta

- An island-wide conference on environmental issues

- Two public presentations and three times media coverage of the science of structured dialogic design and win-win models

- An SDDP engaging civil society and media actors to envision a better media landscape for Cyprus (for reports and publications refer to NML Wiki).

- A new UNDP funded project to promote multiculturalism within the Cypriot educational system (for reports refer to Multicultural Schools website).

- Preparatory steps towards the establishment of a permanent virtual school to train facilitators from across the world in the science of structured dialogic design.

The application of structured dialogue served primarily those who participated. During the previous co-laboratory (Laouris et al. 2009), they achieved a better and a shared understanding of the challenging situation in which they are immersed. The co-Laboratory reported here assisted them to jointly propose options that could facilitate changes and achieve progress. The structured dialogue process helps stakeholders design their own futures using the consensus maps as roadmaps to develop strategies and implement actions. To make progress, one must concentrate on those ideas, which are most influential. The participants focused their future actions precisely on those drivers. In conclusion, one can state with confidence that the options' phase SDDP has not only supported the participants to agree on actions, but moreover it has empowered them to take that magical step towards materializing their ideas, in line with the principles of the Law of Requisite Action (Laouris et al. 2008, 2009). 


\section{Credits}

The Cyprus-EU Association and the Cyprus Intercultural Training Initiative, in collaboration with the Peace Center, the Cyprus Policy Center and the Institute for 21st Century Agoras, organized the co-laboratory. The co-laboratory was organized in the context of a larger project named "Civil Society Dialogue," which was partly funded by USAID/ UNDP. This work would have not been possible without the enthusiastic participation of the twenty Cypriot peace builders, academics and business people, who have invested at least $10 \mathrm{~h}$ each. We especially acknowledge the peace pioneers who have agreed to share their wisdom acquired over a period of ten years of intensive peace work. Special thanks go to the international wing of the Knowledge Management Team and especially to Ken Bausch, Roy Smith, Vigdor Schreibman and Diana Connaway for all their constructive suggestions and criticism. The authors would finally like to thank Larry Fergeson for providing a review of media interventions and CWA Ltd. for providing their proprietary software Cogniscope ${ }^{\mathrm{TM}}$ for use in these workshops.

Open Access This article is distributed under the terms of the Creative Commons Attribution Noncommercial License which permits any noncommercial use, distribution, and reproduction in any medium, provided the original author(s) and source are credited.

\section{References}

Anastasiou H (2007) Nationalism as a deterrent to peace and interethnic democracy: the failure of nationalist leadership from the Hague talks to the Cyprus referendum. Int Stud Perspect 8:190-205

Aziz v Cyprus (2001) European court of human rights. Application no. 69949/01. Available on line: http://www.echr.coe.int/eng/Press/2004/June/ChamberJudgmentAzizvCyprus220604.htm, last accessed June 2008

Banathy BH (1996) Designing social systems in a changing world. Plenum, New York

Broome BJ (1998) Overview of conflict resolution activities in Cyprus. Their contribution to the peace process. Cyprus Rev 10(1):47-66

Broome BJ (2001) Participatory planning and design in a protracted conflict situation Applications with citizen peace-building groups in Cyprus. Syst Res Behav Sci 1:8-19

Broome BJ (2005) Building bridges across the Green Line. A guide to intercultural communication in Cyprus, available in English, Greek and Turkish. UNDP Press, Cyprus

Christakis AN, Bausch K (2006) How people harness their collective wisdom and power. Information Age Publishing, Greenwich. http://www.harnessingcollectivewisdom.comwww.harnessingcollectivewisdom. com

Christophorou C, Webster C (2004) Greek Cypriots, Turkish Cypriots and the future. The day after the referendum. A development associates occasional paper in democracy and governance, vol 16. CYMAR Market Research Ltd., Cyprus

Commission Regulation (2004) (EC) 1480/2004 of 10 August 2004, OJ L 272, 20.8.2004, p 3

Commission Regulation (2005) (EC) 601/2005 of 18 April 2005, OJ L 99. p 10

Commission Regulation (2007) (EC) 330/2007 of 4 May 2007, OJ L 123, 12.5.2007. p 30

Council Regulation (2004) (EC) No 866/2004 of 29 April 2004 on a regime under Article 2 of Protocol 10 to the Act of Accession, Off J Eur Union L 161 of 30 April 2004

Cyprus Civil Society Dialogue Project http://www.civilsocietydialogue.net, last accessed 31 Dec 2008

Cyprus MediaNet http://mirror.undp.org/cyprus/projects/project_details.asp?ProjectID=33

Droushiotis M (2005) The construction of reality and the mass media in Cyprus. Available on line at: http://www.makarios.ws/upload/20051111/1131713084-12865.pdf

DOĞAN Articles relating tech4peace with American interests, e.g. http://www.forumvadisi.com/buvatan-bizim/343269-sn-aydin-dogan-ve-gercekler-gercek-olabilirmi.html, last accessed 20 Dec 2008

Dye K (1999) Dye's law of requisite evolution of observations. In: Christakis AN, Bausch K (eds) How people harness their collective wisdom and power. Information age publishing, Greenwich, pp 166-169 
Dye KM, Conaway DS (1999) Lessons learned from five years of application of the CogniScope. Approach to the food and drug administration, CWA report. Interactive Management Consultants, Paoli

EuropaWorld (2004) Great disappointment at result of cyprus referendum. On line at: http://www.europa world.org/week175/great30404.htm, last accessed 20 Dec 2008

E-voices http://mirror.undp.org/cyprus/projects/project_details.asp?ProjectID=34, last accessed 31 Dec 2008

Green Line Regulation (2004) Corrigendum to council regulation (EC) No 866/2004 of 29 April 2004 on a regime under Article 2 of Protocol 10 to the Act of Accession. Official Journal of the European Union L 161 of 30 April 2004

Green Line Regulation amendments (2005) Council Regulation (EC) 293/2005 of 17 February 2005, OJ L 50, 23.2.2005, p 1

Laouris Y (2004) Information technology in the service of peace building. The case of Cyprus. World Futures 60:67-79

Laouris Y, Anastasiou H (1998) Confidence buildings measures made in Cyprus by Cypriots for Cypriots; creative innovation for transcendence. CYBERKIDS Press, Nicosia

Laouris Y, Christakis A (2007) Harnessing collective wisdom at a fraction of the time using Structured Design Process embedded within a virtual communication context. Int J Appl Syst Stud 1(2):131-153

Laouris Y, Laouri R (2008) Can information and mobile technologies serve close the gap and accelerate development? World Futures 64(4):254-275

Laouris Y, Michaelides M (2007) What obstacles prevent practical broad-band applications from being produced and exploited? In: Patrick R (ed) Towards an inclusive future impact and wider potential of information and communication technologies, Chap 7. Available on line at: http://www.tiresias. org/cost219ter/inclusive_future/inclusive_future_ch7.htm

Laouris Y, Michaelides M, Sapio B (2007) What are the obstacles that prevent the wide public from benefiting and participating in the broadband society? In: Conference proceedings cost 298 conference, Moscow 2007. Available on-line at www.cost298.org

Laouris Y, Laouri R, Christakis A (2008) Communication praxis for ethical accountability: the ethics of the tree of action: dialogue and breaking down the wall in Cyprus. Syst Res Behav Sci 25:331-348

Laouris Y, Michaelides M, Damdelen M, Laouri R, Beyatli D, Christakis A (2009) A systemic evaluation of the state of affairs following the negative outcome of the referendum in Cyprus using the structured dialogic design process. Syst Pract Action Res 22(1):45-75

Multicultural schools (2008) On line at www.multiculturalcyprus.net, last accessed 20 Dec 2008

NML Wiki. Report available online at http://cyprusmedia.wetpaint.com/page/SDDP+Report, last accessed 31 Dec 2008

PSEKA (2003) Disappointment among ordinary Greek and Turkish Cypriots. http://news.pseka.net/index. php?module $=$ article $\& i d=3447$, last accessed 20 Dec 2008

Schreibman V, Christakis AN (2007) New agora new geometry of languaging and new technology of democracy: the structured design dialogue process. Int J Appl Syst Stud 1(1):15-31

Simerini (2004) Newspaper relating tech4peace funding with "yes" campaign during the referendum. 27 Oct 2004 p 4 and 29 Oct 2004 p 6

Soyzal M (1999) A solution for Cyprus through statehood. PERCEPTIONS. J Int Affairs 4(3):1-7

Tech4Peace. At www.tech4peace.org. More information about at: http://mirror.undp.org/cyprus/projects/ project_details.asp?ProjectID=105, last accessed 31 Dec 2008

Tsivacou I (1997) The rationality of distinctions and the emergence of power. A critical systems perspective of power in organizations. Syst Res Behav Sci 14:21-34

Tymvios case (2003) available at: http://www.echr.coe.int/Eng/Press/2003/july/JudgmentEugenia_ Michaelidou\&Michael_TymviosvTurkeyandDemadesvTurkey31July2003.htm and http://www. observercyprus.com/observer/NewsDetails.aspx?id=2788, last accessed 20 Dec 2008

UNDP website: http://www.undp-act.org/MAIN/default.aspx, last accessed 31 Dec 2008

UNOPS website http://www.undp-unops-pff.org/News.asp?Pg=4\&CiD=63\&NewID=530, last accessed 31 Dec 2008

Warfield JN (1988) The magical number three, plus or minus zero. Cybernetics Syst 19:339-358

Warfield JN (1995) Spreadthink: explaining ineffective groups. Syst Res 1(1):5-14

Warfield JN (2009) The Wandwaver solution. Available on line at http://www.gmu.edu/departments/ t-iasis/wandwaver/app12.htm, last accessed 20 Dec 2008

Warfield JN, Cardenas AR (1994) A handbook of interactive management. Iowa State University Press, Ames

Wolleh O (2001) Cyprus: citizen's rapprochement by the bi-communal trainer group. Berhof report no. 8. Berghof Research Center for Constructive Management, Berlin 